\title{
A Educação de Jovens e Adultos no Espaço Prisional: sentidos da escolarização para mulheres em privação de liberdade
}

\author{
Pollyana dos Santos*
}

Olga Celestina da Silva Durand**

\section{Resumo}

O direito à Educação na Prisão baseia-se no princípio constitucional de direito à educação para todos. As especificidades do contexto prisional demandam o desenvolvimento de políticas educacionais capazes de atendê-las. O presente artigo tem como objetivo analisar de que forma a Educação de Jovens e Adultos se insere no espaço prisional e quais seriam os sentidos da escolarização para as mulheres estudantes em privação de liberdade. A pesquisa que inspirou este trabalho teve a intençáo de responder ao seguinte problema: quais os sentidos das experiências escolares vividas por mulheres em privação de liberdade nos diferentes momentos de suas trajetórias de vidas? Para tal, orientou-se por um trabalho de abordagem quanti-qualitativa e contou com os instrumentos de coleta de dados: análise documental, observação participante, entrevistas e aplicação de questionários. Ao analisar as experiências escolares tecidas na escola do presídio foi possível notar um movimento de entrada e permanência na escola: a princípio, a aproximação se justificava pela ocupação do tempo ocioso ou pela remição de dias de pena, entretanto, essa relação com os estudos era redimensionada quando se (re)descobria o gosto por estudar. O lugar ocupado pela instituição escolar e a concepçáo de EJA para os espaços prisionais contribuíram para dar novo sentido à escolarizaçáo: recuperavam-se os nomes, a historicidade da trajetória de vida das estudantes e problematizava-se sobre as condiçóes de vida e os motivos que levaram a cometer crimes, bem como se tornavam possíveis projeçóes para um futuro.

Palavras-chave: Educação de Jovens e Adultos. Mulheres em privação de liberdade. Sentidos da Escolarização.

\footnotetext{
* Mestre em Educaçáo pela Universidade Federal do Espírito Santo (UFES). Doutoranda em Educaçáo na Universidade Federal de Santa Catarina (UFSC). Professora do Instituto Federal Catarinense (IFC), Campus Videira.

** Doutora em Educação pela Universidade de São Paulo (USP). Professora do Programa de Pós-Graduação em Educação da Universidade Federal de Santa Catarina (UFSC).
} 
O presente artigo apresenta um recorte da tese de doutorado em andamento intitulada "Os sentidos das experiências escolares nas trajetórias de vida de mulheres em privação de liberdade", desenvolvida no Programa de Pós-Graduaçẫo em Educação da Universidade Federal de Santa Catarina (UFSC). O referido trabalho tem como objetivo principal: analisar quais são os sentidos das experiências escolares vividas por mulheres em privaçáo de liberdade nos diferentes momentos de suas trajetórias de vidas e teve como locus de investigação um presídio feminino situado na cidade de Florianópolis. Foram sujeitos da pesquisa, mulheres em diferentes faixas etárias estudantes das turmas de Educação de Jovens e Adultos existentes no referido espaço prisional. A coleta de dados foi realizada entre os meses de fevereiro a novembro de 2012 e contou com os seguintes instrumentos: análise de documentos, observação participante, entrevistas e aplicação de questionários.

A população carcerária feminina, embora significativamente menos expressiva quando comparada à parcela de homens no sistema prisional, tem apresentado um aumento preocupante nos últimos anos. O Sistema Integrado de Informaçóes Penitenciárias (Ifopen) ${ }^{1}$ divulgou em 2009 as estatísticas sobre a populaçáo carcerária no Brasil as quais apontavam que, no quinquênio 2003-2007, houvera um crescimento real da população carcerária feminina de $37,47 \%$, o que representava um crescimento de aproximadamente $11,19 \%$ ao ano.

Em 2011, um novo recorte foi realizado para acompanhar o crescimento da população carcerária nos últimos cinco anos. Segundo os Dados Consolidados e os Relatórios Estatísticos Do Sistema Prisional (2005 a 2010), tem-se que dos 296.919 encarcerados/as no sistema prisional brasileiro, 12.925 eram mulheres, no ano de 2005. Em 2010, a populaçâo carcerária brasileira totalizava 445.705 presos e presas, indicando um crescimento de aproximadamente $33,4 \% \mathrm{em}$ relação ao ano de 2005. Desse total, 28.188 eram mulheres, que representavam $6,3 \%$ dos privados de liberdade. Sendo assim, observou-se que o crescimento da população carcerária feminina apresentou uma evolução de 54,1\% em um intervalo de cinco anos, enquanto o crescimento de homens encarcerados tenha se expressado em, aproximadamente, $32 \%$.

O número expressivo do aumento da população carcerária feminina nos chama a atenção para compreender as razóes que envolvem esse processo, principalmente quando um recorte etário é realizado: cerca de metade das mulheres em privação de liberdade encontram-se na faixa etária de 18 a 29 anos. 
O Estado de Santa Catarina contava com 1.170 mulheres privadas de liberdade, no ano de $2010^{2}$, distribuídas nas diversas unidades do sistema prisional catarinense cumprindo os regimes provisório, fechado, semiaberto, aberto e em medida de segurança-internaçáo.

Em relaçáo aos dados sobre escolaridade, que nos interessa em especial para este artigo, observou-se a existência de um maior número de interrupçóes das trajetórias escolares durante o Ensino Fundamental. Embora as estatísticas fornecidas pelo Infopen (ano 2010) náo informassem se esses dados se referiam à situação precedente ou atual das mulheres privadas de liberdade, obtivemos os seguintes índices de escolaridade da população prisional feminina do sistema penitenciário catarinense: 36,8\% das detentas apresentaram o Ensino Fundamental incompleto, seguido de 23,9\% internas alfabetizadas, 16,3\% com Ensino Fundamental completo, 9,4\% com Ensino Médio incompleto, 7,6\% com Ensino Médio completo, 5\% analfabetas, 0,6\% com Ensino Superior incompleto e $0,1 \%$ com Ensino Superior completo.

Diante desses dados, a pesquisa que inspirou este artigo se orientou pelos seguintes questionamentos: 1) considerando que a maioria das jovens mulheres presas cresceu sob a política de proteçấo integral da criança e do adolescente estabelecida a partir do Estatuto da Criança e do Adolescente - que tem como base de ação o princípio educativo -, como explicar o aumento de jovens na população carcerária brasileira?; 2) considerando o direito à escolarizaçáo durante o cumprimento de pena, qual a parcela da população carcerária feminina que realmente frequenta as aulas no presídio?; como seriam as ações de educação direcionadas a esse público?; quais seriam as experiências de escolarização vivenciadas por essas mulheres ao longo da vida?; o que as levaria ao retorno à escolarização no presídio?

Tais questionamentos conduziram ao seguinte problema de investigação: quais os sentidos das experiências escolares vividas por mulheres em privação de liberdade nos diferentes momentos de suas trajetórias de vidas?

Sendo assim, este artigo se propóe em analisar como a Educação de Jovens e Adultos (EJA) se insere no espaço prisional e quais seriam os sentidos da escolarização para as mulheres estudantes em privação de liberdade. Para tal, serão apresentadas as políticas de educação destinadas aos espaços prisionais e 
as concepçōes que envolvem as práticas educativas desenvolvidas nas prisōes brasileiras e, em seguida, como as estudantes percebem a implementação de tais políticas e como dão sentido às práticas educativas das quais são público principal.

\section{A pesquisa realizada}

O complexo penitenciário no qual foi realizada a pesquisa congregava também as seguintes instituiçôes: o Presídio Masculino, a Penitenciária Masculina, o Centro de Observação e Triagem (COT), o Hospital de Custódia e Tratamento Psiquiátrico (HCTP), a Casa do Albergado e o Presídio Feminino.

O Presídio Feminino estava localizado em uma área mais baixa do terreno, ao lado oposto ao Presídio Masculino. Neste espaço, havia uma única sala de aula para atender todas as turmas. Era de um tamanho razoável comparada às demais dispostas nas unidades do complexo; um pouco escura, as paredes eram pintadas de branco com trabalhos realizados pelas estudantes afixados. Uma estante com alguns livros e um armário fechado dispunham-se em uma lateral da sala. Do outro lado, cadeiras "de braço" posicionavam-se de frente para o quadro de giz e para a mesa do professor. Uma grade separava o interior da sala de aula do lado externo e permanecia trancada durante todo o período em que professores e estudantes estavam lá dentro.

A pesquisa que inspirou este texto se propôs a um trabalho quantiqualitativo. Além do levantamento bibliográfico acerca da temática da pesquisa, realizaram-se análise de documentos, observaçôes, aplicação de questionários e entrevistas com professores e mulheres em privaçáo de liberdade.

O primeiro contato com o campo de pesquisa se deu em dezembro de 2011, quando foi agendada uma reunião com a então diretora do presídio feminino. Na mesma semana, foi nomeada nova pessoa para ocupar a direçâo da unidade feminina e os contatos precisaram ser adiados para o ano seguinte. Assim, o novo encontro para apresentação da proposta de pesquisa realizouse no dia 2 de março de 2012, dessa vez, com a presença da coordenaçáo do centro de educação de jovens e adultos do complexo penitenciário. A partir da aprovação dos de coleta de dados empíricos pela escola, fomos apresentados à nova gerência do presídio feminino no dia 15 de março de 2012.

Os trâmites de aprovação da pesquisa envolveram encaminhamentos de solicitação de autorização para realizar da coleta de dados contendo a 
descrição das atividades que seriam realizadas, o tempo previsto para o período de investigação e os dias da semana em que as observação seriam feitas. Esses requerimentos foram endereçados à gerência do presídio feminino, à direção do complexo penitenciário de Florianópolis, à coordenação da escola e à direção do Centro de Educação de Jovens e Adultos.

As observaçóes ocorreram nos períodos de março a novembro de 2012, realizadas em dois dias na semana, totalizando uma carga horária de $6 \mathrm{~h}$ por dia - havendo alterações em função das eventualidades do campo de pesquisa. Nesses dias, era possível acompanhar as três turmas atendidas pelo presídio feminino e ter acesso às estudantes durante o período das aulas.

As mulheres do presídio se aproximavam aos poucos e mostravam suas histórias também aos poucos. A princípio, o narrar se dava pelo silêncio. Os olhares e os sorrisos confirmando que entendiam porque falar sobre suas vidas era importante estabelecia um canal de comunicação. Após um tempo de convivência, as suas vidas eram contadas durante as aulas em falas soltas, compartilhadas como "experiências" entre pares. Depois, eram narradas a mim, enquanto solicitavam ajuda para fazer uma atividade, ou em "conversa paralela" durante as explicaçóes dos professores, que permitiam e fingiam não perceber. Quando a conversa se alongava era a hora da intervenção.

As entrevistas realizadas envolveram dois grupos: professores e estudantes - neste artigo, fez-se o recorte para as falas deste último. A direção do presídio feminino não autorizou a gravação das entrevistas com as presidiárias. Desse modo, as conversas foram registradas "a mão" e, posteriormente, foram transcritas. Para as entrevistas individuais realizadas com os professores, o critério de seleção foi, para além da disponibilidade para conceder a entrevista, ser o docente em cujas aulas foram desenvolvidas as observaçóes. Para as mulheres estudantes privadas de liberdade, não houve um critério de seleção para participar das entrevistas em grupo.

Assim, os grupos de estudantes entrevistados respeitaram a divisão das turmas: Alfabetização/Nivelamento, Ensino Fundamental e Ensino Médio. Participaram desse momento todas as mulheres que estavam presentes na aula no dia da aplicação desse instrumento (sendo este, talvez, o único critério de seleção das entrevistas), a saber: 1) Turma da Alfabetização/Nivelamento - 10 estudantes; 2) Turma do Ensino Fundamental - 2 estudantes; Turma do Ensino Médio -5 estudantes. As entrevistas realizadas nesses grupos se realizaram por meio de roteiros semiestruturados. 


\section{A Educação de Jovens e Adultos nos espaços prisionais}

A defesa pela educaçáo em unidades prisionais se baseia no "princípio maior", constitucional, do direito à educação a todos. Entretanto, entre o amplo direito ao acesso à escolarização e a concretização de políticas educacionais destinadas à população privada de liberdade, há uma trajetória de lutas e enfrentamentos para sua realizaçáo.

Timothy D. Ireland (2011, p. 21) atenta para a importância de reconhecer a educação nas prisōes como "uma expressão da educação de jovens e adultos voltada para uma população e um contexto específico". Para melhor compreendê-la, o autor recupera a definição mais ampla de educação de jovens e adultos expressa na Recomendação de Nairob, de 1976:

A expressão "educação de adultos" designa o conjunto de processos organizados de educação, qualquer que seja o seu conteúdo, o nível e o método, quer sejam formais ou não formais, quer prolonguem ou substituam a educação inicial dispensada nos estabelecimentos escolares e universitários e sob a forma de aprendizagem profissional, graças aos quais pessoas consideradas como adultas pela sociedade de que fazem parte desenvolvem as suas aptidóes, enriquecem os seus conhecimentos, melhoram as suas qualificações técnicas ou profissionais ou lhe dão uma nova orientaçáo, e fazem evoluir as suas atitudes ou o seu comportamento na dupla perspectiva de um desenvolvimento integral do homem e de uma participação no desenvolvimento socioeconômico e cultural equilibrado e independente [...]. (UNESCO, 1976, p. 2 apud IRELAND, 2011, p. 26).

Para o autor, compreender a educaçáo de jovens e adultos nos espaços prisionais implicaria também em percebê-la a partir da premissa de aprendizagem ao longo da vida. Nesse sentido, os processos educativos seriam entendidos a partir de um tripé: as aprendizagens tecidas nos sistemas formais de ensino, nas instituiçóes escolares; as experiências educativas tecidas em espaços não formais de educação, mais flexíveis e vinculadas aos interesses ou necessidades dos sujeitos, como por exemplo, a formação profissional; os processos educativos envolvidos na educação informal, que se referem às aprendizagens desenvolvidas 
nas relações com os outros em nossa experiência cotidiana - "aprendemos em muitos espaços e de múltiplas formas, dos quais escapam as atividades que possuem objetivos educacionais" (IRELAND, 2011, p. 26).

Denise Carreira (2009) e Andréa Rettig Nakayama (2011) retomam os marcos legais que orientam o trabalho educativo nas prisóes e apresentam aqueles que poderiam ser considerados os principais para a garantia do direito à educação aos sujeitos privados de liberdade:

- Regras Minimas para o Tratamento de Prisioneiros (Conselho Econômico e Social da ONU): documento internacional de 1957 que prevê o acesso a atividades educativas em meio prisional (inclusive o atendimento de creche para filhos de mulheres detentas e atividades de educação física) ${ }^{3}$;

- Declaraçáo de Hamburgo e o Plano de Ação para o Futuro (aprovados na V CONFINTEA, 1999): documentos que garantiram, internacionalmente, o direito à educação do sujeito privado de liberdade, reconhecendo-o como "parte do direito à educaçáo de jovens e adultos no mundo";

- Convençáo contra a Tortura e outros Tratamentos ou Penas Cruéis, Desumanos ou Degradantes (ONU, 1984; Brasil, 1991): Carreira (2009, p. 12) considera este documento internacional como marco legal para garantia de educação em prisóes, pois, ele possibilita o "enquadramento de situaçóes geradas por agentes penitenciários ao criarem resistências e obstáculos cotidianos para o acesso à educação de pessoas privadas de liberdade";

- Constituição da República Federativa do Brasil (1988): assegura o direito à educação a todos os cidadáos;

- Lei de Diretrizes e Bases da Educação Nacional (Lei no 9.394/96): define a Educação de Jovens e Adultos - à qual se integra a educaçáo em espaços prisionais - e regulamenta o direito previsto na Constituição brasileira de 1988 no que se refere ao acesso ao Ensino Fundamental obrigatório e gratuito, inclusive àqueles que não o concluíram em "idade própria";

- Plano Nacional de Educação (PNE-2001): estabelece como meta para a educação no Brasil a implantaçáo e a oferta de programas de educação em todas as unidades prisionais e instituiçóes de atendimento socioeducativas; 
- Lei de Execução Penal (LEP/1984): prevê a educação nos espaços prisionais, como assistência ao sujeito privado de liberdade, nos artigos 17, 18, 19, 20 e 21;

- Diretrizes Nacionais para oferta de educação para jovens e adultos em situação de privação de liberdade nos estabelecimentos penais (Resolução n. 2, de 19 de maio de 2010): fixa as diretrizes para a educação de jovens e adultos nos espaços prisionais, considerando suas especificidades. Carreiro (2009, p.13) apresenta os eixos que compunham os parâmetros para educaçáo de jovens e adultos em estabelecimentos prisionais quando organizados em Projeto de Lei: “(1) gestão, articulação e mobilização; (2) formação e valorização dos profissionais envolvidos na oferta; (3) aspectos pedagógicos".

A esses marcos legais poderiam ser agregados a Lei n. ${ }^{\circ} 12.433 / 2011$, de junho de 2011, e o Decreto $n^{\circ} 7.626 / 2011$, que tratam, respectivamente, da Remiçáo de pena por estudo e do Plano Estratégico de Educaçáo no Sistema Prisional (ambos instituídos pela Casa Civil). Segundo Cátia Alvisi e Dirce Djanira Pacheco e Zan (2011), esses documentos contribuem para a garantia de implementaçáo de políticas públicas que assegurem o direito à educaçáo nos espaços prisionais.

No trajeto de construção de políticas para educação nas prisões foi elaborado o Projeto Educando para a Liberdade, em 2005, cujo objetivo principal era construir açôes articuladas entre as diferentes instâncias envolvidas no sistema prisional para a garantia de condiçóes à oferta da educação em espaços prisionais. Estabelecido por meio do Protocolo de Intenções entre o Ministério da Educação e o Ministério de Justiça, o documento explicitava:

[...] que a oferta de educação possibilita aos presos desenvolver a autonomia e ampliar os seus conhecimentos básicos. A população carcerária tem o direito humano básico à educaçáo, e que este deve centrar-se no desenvolvimento dos presos em todos os aspectos: mental, físico, social e espiritual. Afirma, ainda, que as açôes não devem ser entendidas como assistencialismos, e sim, como política pública garantidora de direitos. Trata-se de formular políticas e metodologias de educaçáo para jovens e adultos que vivem privados de liberdade, mas sem esquecer de contemplar as diferenças como a questão 
de gênero, raça, orientação sexual e de escolha religiosa, capaz de contribuir para a restauração da auto-estima, redução de vulnerabilidade e a volta ao convívio social. (TEIXEIRA, 2010, p. 15).

Teixeira (2010, p. 15) considera que o Projeto Educando para a Liberdade instituiu uma importante ruptura entre as práticas educativas na prisão e a lógica de reintegração social do presidiário ao fundamentar-se no "reconhecimento de que o homem privado de liberdade é um sujeito de direito" e, portanto, a educação se torna para ele um "direito fundamentalmente humano".

Segundo o autor, as avaliaçóes do Projeto apontaram para a ampliação dos debates e das reflexóes sobre a garantia de direitos aos sujeitos privados de liberdade. Nesse mesmo contexto, destacam-se os seguintes avanços:

[...] as açôes de alfabetizaçáo realizadas no âmbito do Programa Brasil Alfabetizado do Ministério da Educação; a oferta do Exame Nacional do Ensino Médio (ENEM), mecanismo importante para o acesso ao ensino superior; a aplicação do Exame Nacional de Certificação de Educaçáo de Jovens e Adultos (ENCCEJA). Destaca-se, também, a inclusão da temática nos fóruns de Educação de Jovens e Adultos e, consequentemente, no documento do governo brasileiro como contribuiçáo para a VI Conferência Internacional de Educaçấo de Jovens e Adultos da Unesco (CONFINTEA). Além disso, ainda no campo da articulação, o Brasil sugeriu a inclusão do tema no âmbito do Consórcio Eurosocial, entre União Européia e a América Latina, o que desencadeou na criação da Red Latinoamericana de Educación em Contexto de Encierro. (TEIXEIRA, 2010, p. 20).

Algumas ações foram tomadas a partir das avaliações do Projeto Educando para a Liberdade: a divulgação de dados referente ao número de presos em atividades educacionais nos registros de Informação Penitenciária no ano de 2008; e o incentivo à criação de Planos Estaduais para fixar diretrizes de atendimento educacional em estabelecimentos prisionais no ano de 2009.

As Diretrizes Nacionais para oferta de educação para jovens e adultos em situação de privação de liberdade nos estabelecimentos penais (Resolução n. 2, de 
19 de maio de 2010) determina o atendimento das especificidades dos diferentes níveis de ensino e modalidades de educação a homens e mulheres privados de liberdade que se encontrem em regimes provisórios, em cumprimento de pena, que sejam egressos/as do sistema prisional e que cumpram medida provisória (BRASIL, 2010).

São responsáveis pela oferta de educação nos estabelecimentos penais estaduais (como no caso do presídio feminino lócus de investigação da pesquisa) o órgão responsável pela Educação (Secretaria de Educação) em articulação com órgãos responsáveis pela Administração Penitenciária (Art. 3º, parágrafo I). A referida resolução também estabelece que o custeio da educação em estabelecimentos penais provirá da parcela destinada à modalidade da Educação de Jovens e Adultos no Fundo de Manutenção e Desenvolvimento da Educação Básica e de Valorização dos Profissionais da Educação (FUNDEB).

Ainda no artigo terceiro da Resoluçáo n. 2, de 19 de maio de 2010, os parágrafos IV, VII, VIII contemplam as especificidades da ação pedagógica nos espaços prisionais e a necessidade de uma prática flexível que considere: o atendimento diferenciado para os diferentes regimes prisionais e oferta de ensino em todos os turnos; as diversidades étnico-raciais, de gênero, de idade e as demandas por educação inclusiva; a flexibilidade no regime de matrícula, na oferta de aulas e na organizaçáo curricular (BRASIL, 2010).

No que se refere à gestáo da educaçáo em estabelecimentos prisionais, o artigo sexto da Resolução propóe que a "formulação, execução, monitoramento e avaliação de políticas públicas de Educação de Jovens e Adultos em situação de privação de liberdade" (BRASIL, 2010) sejam realizados por meio de articulaçóes com diferentes áreas de governo, instituiçóes de educação profissional, universidades e organizaçóes da sociedade civil. Essa garantia legal se torna importante por promover o estreitamento dos vínculos entre o "mundo interno" das prisóes e o "mundo externo", rompendo com a consolidação de instituições totais que têm suas atividades conclusas em suas rotinas e regras. Ao considerar a necessidade de envolvimento de outras instâncias e esferas para além do espaço prisional, concebem-se novas e diferentes formas de pensar a pena de privação de liberdade.

No bojo das propostas construídas para a oferta de atividades educacionais nas prisōes, encontram-se diferentes paradigmas ou tendências que exprimem o que se espera (ou o que se pensa) da educação oferecida nos espaços de privação de liberdade. Carreira (2009) apresenta os modelos educativos predominantes 
nos sistemas prisionais na América Latina enumerados pelo Relator Especial da ONU sobre Educação, Nernor Muñoz. Seriam três os que mais se destacam:

1. Educação como tratamento terapêutico com vistas à cura do encarcerado;

2. Educação como correção dos desvios morais das pessoas "intrinsecamente imorais";

3. Educação nas prisóes como prática a serviço do mercado de trabalho.

Modelos semelhantes são apontados por Julião (2007), que indica nas suas pesquisas, que as políticas educativas desenvolvidas no espaço prisional assumem diferentes conotações: ora ela atende a uma lógica de ocupação do tempo ocioso, ora ela representa um meio para a ressocialização do presidiário.

Essas percepçóes acerca da educação nos espaços prisionais sufocam as especificidades dessa modalidade e minimizam o principal objetivo das açóes que é a garantia do direito humano à educaçấo. A garantia dos direitos do sujeito privado de liberdade se agrava ao se observar a política criminal assumida pelo Brasil que conduz ao aumento das prisóes em regime fechado, dificultando, assim, o estabelecimento de condições mínimas de sobrevivência nas unidades penais (WACQUANT, 2001; JULIÃO, 2007).

Sendo assim, a partir das trajetórias de políticas educacionais para a EJA em espaços prisionais, dos enfoques ou paradigmas que fundamentaram e ainda oferecem suporte a diferentes práticas desenvolvidas nos presídios brasileiros, algumas questôes aparecem: que sentidos são possíveis para a escolarização desenvolvida nos espaços prisionais? Como ela acontece? O que pensam os estudantes sujeitos da ação educativa?

\section{Os sentidos da escolarização na prisão}

Neste trabalho, recorre-se a Charlot (2000) e a Miller (2011) para esboçar nossa compreensão acerca do que venha ser "conferir" sentido à educação (e em nosso caso, especificamente, à educação escolar).

Ambos os autores partem do princípio de que o homem, ao nascer, não traz em si todas as características do ser humano. Ou seja, diferente de outros animais, a espécie humana nasce sem todas as "atribuiçōes" de seus antecedentes; para "tornar-se humano", para constituir-se "homem", é preciso aprender a sê-lo a partir das relaçóes sociais. Desse modo, segundo Charlot (2000): 
Nascer é penetrar nessa condição humana. Entrar em uma história, a história singular de um sujeito inscrita na história maior da espécie humana. Entrar em um conjunto de relaçôes e interaçôes com outros homens. Entrar em um mundo onde ocupa um lugar (inclusive, social) e onde será necessário exercer essa atividade. Por isso mesmo, nascer significa ver-se submetido à obrigação de aprender. Aprender para constituir-se, em um triplo processo de "hominização" (tornar-se homem), de singularização (tornar-se exemplar único de homem), de socialização (tornar-se membro de uma comunidade, partilhando seus valores e ocupando um lugar nela). [...] Nascer, aprender, é entrar em um conjunto de relaçóes e processos que constituem um sistema de sentido, onde se diz quem eu sou, quem é o mundo, quem sáo os outros.

Esse sistema se elabora no próprio movimento através do qual eu me construo e sou construído pelos outros, esse movimento longo, complexo, nunca completamente acabado, que é chamado educaçáo (CHARLOT, 2000, p. 53, grifo nosso).

Para Charlot (2000), a educação seria esse movimento pelo qual o ser "constrói a si mesmo" e "por si mesmo", e que esse processo pode ser concebido e mediado pelo educador de antemáo. As finalidades de educar alguém podem ser previamente estabelecidas por aquele responsável por essa tarefa. Entretanto, ela somente acontecerá se o educando assim o permitir, ou se "interessar em". Segundo o autor, para que a educação aconteça é preciso que o outro "invista pessoalmente no processo que o educa" (CHARLOT, 2000 , p. 54). Por outro lado, também se faz necessário que haja a relação com os outros e com o mundo para que esse processo se concretize. "A educação é impossível, se a criança não encontra no mundo o que lhe permite construirse" (CHARLOT, 2000, p. 54).

Segundo o que nos inspira Charlot (2000), a educação parece ser possível quando o educando movimenta-se ("mobiliza-se") por alguma boa razão ("móbile") a desenvolver um conjunto de atividades a fim de satisfazer um desejo que o resultado ("meta") desse processo pode satisfazer. $\mathrm{O}$ exemplo trazido pelo autor auxilia a entender essas relaçôes: 
A criança mobiliza-se, em uma atividade, quando investe nela, quando faz uso de si mesma como de um recurso, quando é posta em movimento por móbeis que remetem a um desejo, um sentido, um valor. A atividade possui, então, uma dinâmica interna. Não se deve esquecer, entretanto, que essa dinâmica supõe uma troca com o mundo, onde a criança encontra metas desejáveis, meios de ação e outros recursos que não ela mesma. (CHARLOT, 2000, p. 55).

Para que haja a mobilização do educando para mover recursos para desempenhar atividades é preciso que essa ação tenha sentido. $\mathrm{O}$ autor define sentido a partir do seguinte raciocínio:

[...] têm sentido uma palavra, um enunciado, um acontecimento que possam ser postos em relação com outros em um sistema, ou em um conjunto; faz sentido para um indivíduo algo que lhe acontece e que tem relaçôes com outras coisas de sua vida, coisas que ele já pensou, questôes que ele já propôs. É significante (ou, aceitando-se essa ampliação, tem sentido) o que produz inteligibilidade sobre algo, o que aclara algo no mundo. É significante (ou, por ampliação novamente, tem sentido) o que é comunicável e pode ser entendido em uma troca com outros. Em suma, o sentido é produzido por estabelecimento de relação, dentro de um sistema, ou nas relaçôes com o mundo ou com os outros. (CHARLOT, 2000, p. 56).

Charlot também estabelece uma distinção entre as definiçốes de "sentido" relacionada à "desejabilidade" e "sentido" indicando "significação". Para o primeiro caso, o "sentido de alguma coisa" estaria relacionado ao nível de importância que ela assume para o sujeito, ou seja, "quando eu digo que isso tem realmente sentido para mim, estou indicando que dou importância a isso, que para mim isso tem um valor" (CHARLOT, 2000, p. 57). Na segunda situação, "quando digo que 'não entendo nada', isso quer dizer simplesmente que o enunciado ou o acontecimento não tem significado", ou seja, seria vazio de sentido (CHARLOT, 2000, p. 57).

Miller (2011) insere as relações significado-sentido no processo de ensino e de aprendizagem no domínio da linguagem. Com base em Leontiev 
e Vygotski, a autora define significado e sentido. Na interação discursiva, o significado é estável e "vive sob formas estabelecidas socialmente e que permanecem disponíveis ao usuário para que delas se utilize nos diferentes contextos comunicacionais pelos quais transita" (MILLER, 2011, p. 5). Nos enunciados que nos são endereçados o significado exprime o que a palavra diz, a que ela se refere. A sua compreensão possibilita se inserir na vida social, entender e se fazer entendido pelos outros.

O sentido, por sua vez, relaciona-se à forma como o sujeito interpreta, sente ressoar em si os significados presentes na interação discursiva. Por essa razão, ele varia conforme o contexto em que os significados são enunciados, como foram endereçados e como são sentidos pelo outro. Sua constituição se relaciona com:

[...] o que Vigotski denominou "experiência emocional". Uma experiência emocional é uma unidade que, de um lado, representa algo que está fora da pessoa, ou seja, aquilo que está sendo experimentado por ela (a própria situação vivida por ela) e, de outro, aquilo que representa o que essa pessoa está sentido com essa experiência, como a situação é vista, é percebida por ela. (MILLER, 2011, p. 5).

Como essa relação seria estabelecida no processo de ensino e de aprendizagem? A autora compreende que a escola é a instituiçáo responsável pela transmissão sistemática dos conhecimentos históricos e socialmente construídos pela humanidade. Sendo assim, os saberes expressos em conteúdos organizados pela escola se expressam como significados, são os conceitos de uma área de conhecimento. Para que o professor consiga transmitir tais conceitos é necessário que se estabeleça na relação de ensino e de aprendizagem os motivos pelos quais tais conteúdos se fazem necessários ou importantes para a vida do estudante. Para isso, é relevante considerar como o sujeito a quem se direciona a açáo educativa percebe, sente e vê essa situação da qual ele faz parte. Desse modo,

Enfatizamos, entretanto, que o aluno inserido em sua atividade de estudo, a exemplo do trabalhador inserido em seu trabalho, só vê sentido em realizá-la quando essa atividade se mostra por inteiro a ele, ou seja, quando as açóes que ele realiza estáo direcionadas pelo motivo que 
gerou a atividade como um todo e que dá ao aluno a oportunidade de ver-se no produto dela decorrente. Caso isso náo ocorra, e as açóes de estudo sejam pontualmente realizadas, sem que formem uma cadeia direcionada pelo motivo de uma atividade cuja finalidade corresponda a esse motivo que a gerou, o produto dessas açôes pode parecer ao aluno como algo fora de si, externo a ela, alienado. Isso causa nele um estranhamento com relação ao produto de sua ação, e, com isso, o sentido que esse produto tem para sua vida se perde. (MILLER, 2011, p. 9).

Assim, segundo a autora, a atividade educativa desenvolvida na escola envolve não apenas a seleção e transmissão dos conceitos socialmente construídos pela humanidade, mas a ação conjunta de professores e estudantes na compreensão desses conhecimentos de modo que se considere "as expectativas dos alunos quanto ao valor desse conhecimento para sua vida" (MILLER, 2011, p. 11).

Estabelecendo uma relação entre os dois autores, é possível perceber que a produção de um sentido para a atividade educativa envolve a mobilização dos estudantes a fim de compreender a necessidade, a importância ou o valor de se dispor ao processo educativo proposto pela instituição escolar. Essa compreensão se faz necessária para a análise proposta neste artigo que envolve: quais são as memórias das experiências escolares envolvidas no processo de escolarização desenvolvido no espaço prisional; como são percebidas as açóes voltadas para a educação no espaço prisional e como se percebem nesse processo a fim de entender que sentidos são produzidos para a escolarização no presídio feminino pesquisado.

Uma vez que a proposta seria analisar quais os sentidos atribuídos à escolarização no espaço prisional, faz-se necessário compreender como essa prática se insere na complexidade do sistema penitenciário.

Onofre (2007) apresenta o complicado lugar da educação nos espaços penitenciários. Enfrenta-se a contraditoriedade entre a forma como se estrutura o sistema prisional e o que se espera que a educação proporcione aos estudantes. Assim, enquanto o sistema prisional prioriza a repressão, a perda de identidade do preso, o confinamento, a vigilância, a violência e a punição (embora a existência destes últimos não seja assumida como prática recorrente em presídios), a educação formal prima por promover a liberdade, a comunicação 
e a promoção humana. Citando Saviani (1980 apud ONOFRE. 2007, p. 23), a autora compreende que a educação no presídio sempre estará preocupada em "[...] tornar o homem cada vez mais capaz de conhecer os elementos de sua situação para intervir nela, transformando-a no sentido de uma ampliação da liberdade, da comunicação e da colaboração entre os homens".

Santos (2007) também problematiza o papel/função da escola no espaço prisional. Para o autor, o sentido da educação na prisão perpassa as relaçôes estabelecidas entre os sujeitos no espaço escolar. Para ele, a figura do professor se institui para o encarcerado como "uma possibilidade de trazer para dentro da prisão os acontecimentos culturais, políticos e econômicos ocorridos fora dos muros da penitenciária" (SANTOS, 2007, p. 106).

O autor se aproxima de Onofre (2007) ao considerar que a escola na prisão deva promover a "autonomia do interno, a problematização de sua existência e a promoção de dignidade". Ele analisa que:

[...] quaisquer que sejam as funçôes atribuídas à escola da prisão, os detentos têm dela expectativas positivas, sendo um lugar de vivências interativas, de respeito mútuo, de cooperaçáo e que, no limite, contribui para tornar a pena privativa de liberdade menos dolorida. (SANTOS, 2007, p. 107).

Ireland (2010, p. 30), partindo da premissa de educação como direito fundamental do ser humano, questiona "qual seria uma educação socialmente relevante para os jovens e adultos reclusos". Diante do movimento contraditório assumido pela EJA nos espaços prisionais como ele se afirmaria no presídio como política educacional? Para o autor,

Afirmamos que uma boa educação deveria partir da experiência dos sujeitos, valorizar os seus conhecimentos e atender as suas necessidades de aprendizagem. Também para educar é necessário ter uma visão otimista do futuro. [...] As aprendizagens que o recluso precisa para sobreviver na prisão não são necessariamente as mesmas que precisa para se reintegrar na sociedade ao cumprir sua pena. Como também notamos, a noção de futuro para a maioria dos presos se restringe à data de soltura. (IRELAND, 2010, p. 30). 
Em sequência a essa linha de raciocínio, Ireland (2010) afirma a importância de pensar os processos educativos para além das propostas formais de educação. Segundo o autor, as iniciativas de educação não-formal poderiam melhor se "adequar" às dinâmicas, espaços e tempos de formação no espaço prisional e oferecer mais cursos de duração e natureza diversificadas. Além disso, esses processos educativos formais ou não formais deveriam acontecer de maneira articulada, integrada e não fragmentada como tem sido possível observar nos contextos de privação de liberdade (IRELAND, 2011).

Em ambos os casos, o debate proposto se refere à possibilidade de a educação no espaço prisional estabelecer outros vínculos com o educando que recuperam o "prazer de aprender", uma vez que, estar em uma experiência educativa se faz por opção, por uma açáo voluntariosa do educando.

A escola do complexo penitenciário, apresentava como missão institucional "atender aos privados de liberdade que buscam através da Escola/Educação uma outra oportunidade de vida, proporcionando uma nova leitura de mundo"4.

Mantida a partir de um convênio estabelecido entre a Secretaria de Estado da Educação e a Secretaria de Estado da Justiça e Defesa do Cidadão, a escola atendia a todas as unidades do complexo penitenciário e possuía, no total, 186 estudantes matriculados 5 .

Nas turmas de Alfabetização/Nivelamento estavam matriculados um total de 75 homens e mulheres. Nas turmas do Ensino Fundamental computava-se de 49 matrículas. No Ensino Médio matricularam-se 57 estudantes.

As turmas contavam também com a presença de estudantes ouvintes que frequentavam as aulas sem realizar a matrícula, pois, já possuíam o Ensino Médio Completo. No entanto, como não queriam ficar com a "mente parada", voltavam a estudar. Existiam também, em número muito reduzido, homens e mulheres que cursavam o ensino superior.

Dentre esses dados, a distribuição de matrículas por turmas se encontrava da seguinte forma no Presídio Feminino:

Tabela 1- Número de matrículas por turmas no Presídio Feminino

\begin{tabular}{|l|c|}
\hline \multicolumn{1}{|c|}{ Turmas } & Matrículas \\
\hline Alfabetização/Nivelamento & 13 \\
\hline Ensino Fundamental & 06 \\
\hline Ensino Médio & 14 \\
\hline
\end{tabular}


A escola oferecia aos estudantes matriculados os seguintes exames: Exame nacional para Certificação de Competências de $5^{\mathrm{a}}$ a $8^{\mathrm{a}}$ (ENCCEJA); Exame Nacional Ensino Médio (ENEM); Prova de Vestibular da UFSC.

As instalaçôes físicas da escola eram precárias para o trabalho de professores e estudantes. A rotina de trabalho dos docentes era marcada pelas descontinuidades de diferentes ordens: frequência escolar das estudantes; coordenação do trabalho da escola; horários e impedimentos de entrada em sala de aula quando a intenção era primar pela "segurança" e ordem do presídio. Eis a característica conflitante entre o espaço escolar e o sistema prisional relatada por Onofre (2007): a escola parecia se encontrar enredada nas normas de segurança, vigilância e manutençáo das ordens adotadas pelo complexo penitenciário.

As diferentes turmas se ocupavam daquele mesmo espaço de sala de aula de formas diversas. A turma de Alfabetização/Nivelamento era a mais numerosa, a frequência de estudantes variava entre 10 e 15 mulheres adultas. Ocupavam a sala, todas as tardes, com seus cadernos e materiais escolares decorados com capricho e conversavam sobre diferentes temas durante a aula. A turma de Ensino Fundamental era menor e contava com duas assíduas estudantes (uma adulta e uma jovem). Frequentavam as aulas pela manhã e pareciam curiosas ao que o professor lhes apresentava. A turma de Ensino Médio, por sua vez, era a que apresentava maior flutuação no número de frequências e era composta por uma adulta e por quatro ou cinco jovens.

As trajetórias escolares dessas estudantes tornava possível identificar dois grandes grupos: um primeiro grupo marcado pela exclusão do espaço escolar ainda na infância ou início da juventude, e um segundo grupo caracterizado por certa continuidade nas trajetórias escolares, apresentando poucas rupturas.

Das quinze mulheres entrevistadas, treze ingressaram na escola em idades entre cinco e sete anos. Uma estudante iniciou a vida escolar aos oito anos de idade e para uma mulher matriculada na turma de Alfabetização/ Nivelamento, o início da trajetória escolar se deu no presídio, aos trinta e nove anos de idade.

Se para a maioria o ingresso se deu entre os sete anos de idade, foi também para grande parte das entrevistadas que a interrupção dos estudos aconteceu ainda na infância entre os oito e dez anos. Para as demais, a ruptura na trajetória escolar foi registrada entre quatorze e dezessete anos de idade. Com a exceção 
de uma jovem de vinte e seis anos que já havia concluído o Ensino Médio: "Eu nunca interrompi. Nunca reprovei! Fiquei sem estudar dois meses.' (Estudante, 26 anos, Ensino Médio).

Dentre os principais motivos que causaram rupturas nas trajetórias escolares estão as situações de gênero e de classe social que atravessaram, e ainda atravessam, a vida das mulheres estudantes. Compreende-se que os papéis de gênero são construídos durante a socialização por meio da incorporação do habitus. Desse modo, aprende-se a ser "mulher" e aprende-se a ser "homem" no processo de socializaçáo, introjetando-se, como algo natural, o que a sociedade convenciona ser homem e mulher, o que é esperado para um e para outro e o que pode ser alcançado por um e outro (BOURDIEU, 1999). As estudantes relataram, dentre as atribuiçôes da condição de "ser mulher" o cuidado com a casa, com os filhos e o "respeito" aos maridos e namorados que esperavam que elas cuidassem da casa e deles:

Meu pai não deu estudo pra mim. Ele disse que a fia muié não se dá estudo. Que eu tinha que fazer crivo, bordado. Mas, ninguém deu pra crivo! Quiiii!! Ai, eu casei. Depois que eu casei, tive os filhos... até queria voltar a estudar.. Mas a escola era muito longe! Era perigoso... (Estudante, 64 anos, Alfabetização/ Nivelamento).

Até que no começo [os pais] incentivava [a estudar], mas... depois que o pai morreu, a situação ficou dificill e a gente teve que parar de estudar pra trabalhar. (Estudante, 54 anos, Alfabetização/ Nivelamento).

Com 16 anos [parou de estudar]. No segundo ano do Ensino Médio. Por causa da gravidez. (Estudante, 22 anos, Ensino Médio).

Parei [de estudar] com 14 anos de idade. Porque acabei conhecendo um rapaz e acabei me apaixonando. Larguei dos estudos pra ficar com ele. Ele era envolvido no crime, e conheci o crime também. Acabei me envolvendo. Achei que o estudo não ia me fazê falta. Agora eu vejo o quanto os estudo me faz falta. (Estudante, 20 anos, Ensino Fundamental).

[Parei de estudar] com 15 ou 16 anos. Porque já namorava e queria me casar e o ciúme do meu marido fez com que eu deixasse de estudar. (Estudante, 56 anos, Ensino Médio). 
Ferreira (2005) demonstra, por meio de suas pesquisas, que esses elementos se vinculam à situação de gênero das estudantes da Educação de Jovens e Adultos e representam empecilhos para a continuidade do processo de escolarização:

[...] estudos indicam também outros fatores causadores da evasão de mulheres jovens e adultas da escola, relacionados à segurança física que atinge mais especificamente as mulheres (iluminação, transporte, serviços de segurança). Mas a necessidade de arcar com as responsabilidades familiares ou viver uma situação de subordinação no espaço doméstico são os grandes motivos de evasão das mulheres adultas das escolas. (FERREIRA, 2005, p. 78).

Souza (2013), em seus estudos sobre a EJA em espaços de privação de liberdade e as relaçôes entre os campos teóricos de gênero e currículo, observou em suas análises que a responsabilidade atribuída às mulheres no cuidado com o outro estáo entre os principais motivos de abandono dos estudos, pois levam à necessidade de escolher entre trabalhar para cuidar dos filhos ou irmãos e continuar os estudos.

As memórias que conservavam da escola e de suas experiências escolares apontavam para aulas enfadonhas, professores que marcaram positiva e negativamente, sonhos com futuros profissionais e a alegria proporcionada pelos intervalos do recreio - momento em que a sociabilidade entre os estudantes se torna possível e "liberada". A escola, para as mulheres adultas que se depararam com a obrigaçáo de trabalhar desde muito cedo, possuía ainda a funçáo de garantir a elas o estatuto da infância. Era na escola que podiam ser e eram tratadas como crianças:

É que nós que era presa queria ira pra escola pra brincar! Eu sempre tava no meio daquelas coisas de trabalho... Olha eu me lembro que a minha mãe ganhou os filhos em casa... eu me lembro um que ela teve uma hemorragia e não quis chamar o pai pra ajudar e mandou me chamar. Eu tinha o que? Dez, treze anos? E eu cheguei lá e fique assustada, cheio de sangue... e minha mãe lá. Então, não tinha isso [na escola]... eu desde novinha tava no meio daquelas coisas... (Estudante, 64 anos, Alfabetização/ Nivelamento). 
Após interrupções das trajetórias escolares e das narrativas que relembravam tempos pouco agradáveis, o que as faria retomar os estudos em privação de liberdade? Essa perguntada foi direcionada às estudantes durante a entrevista:

Eu, por causa da remição, né? Que me disseram que tem a remição, né. Tantas horas que estuda tem remição... E também que a gente sempre aprende uma coisinha, né? (Estudante, 39 anos, Alfabetização/ Nivelamento).

Pra ocupar minha mente, recuperar o tempo... A remição... $e$ sair mais rápido! [pausa] Acho que às vezes a gente aprende muito mais no mundo... Às vezes eu acho que a gente aprende mais no mundo que na escola, não tem? A vida... a gente aprende mais na vida. (Estudante, 20 anos, Ensino Fundamental).

Porque tenho muito tempo aqui ainda. [referindo-se à remição].. (Estudante, 22 anos, Ensino Médio).

Eu tenho tempo agora [risos]. (Estudante, 25 anos, Ensino Médio).

Eu vim pela remição, mas acaba que a gente aprende um pouco alguma coisa.. (Estudante, 39anos, Alfabetizaçâol Nivelamento).

A remição parece, à primeira vista, ser o principal motivo/sentido de retorno aos estudos e à vida escolar no presídio. A Lei no 12.433/2011 (BRASIL, 2011), que dispóe sobre a remição de parte do tempo de execução da pena por estudo ou por trabalho, institui, no artigo $126\left(\$ 11^{\circ}\right.$, I), que a cada doze horas de frequência escolar, divididas em no mínimo três dias, torna-se possível remir um dia de pena. Ainda, no mesmo artigo $126\left(\$ 5^{\circ}\right)$ consta que a conclusão do ensino fundamental, médio ou superior pode resultar no acréscimo de $1 / 3$ ao tempo a remir em função das horas de estudo.

Ao tomarmos a Lei no $12.433 / 2011$, é possível compreender por quais razóes a remição seria indicada como uma importante justificativa para o retorno às aulas. As movimentaçóes de educadores que foram realizadas anteriormente à promulgação dessa lei, davam vistas a necessidade conferir ao estudo a mesma 
importância reconhecida à atividade laboral nas unidades prisionais em termos de redução da pena. Entretanto, a remição da pena pelos estudos passa a instituir uma moeda de troca entre escola e estudantes, assumindo para estes uma relação utilitarista com o processo de escolarização.

Provavelmente, a relação entre estudos e diminuição do tempo da pena se vinculasse aos diferentes "níveis de entusiasmo" com as aulas, observados nas três turmas. Nesse entender, parecia que havia sentido frequentar as aulas para as mulheres mais velhas, pois era a única atividade capaz de remir pena que seria destinada a elas no presídio. Provavelmente, esse seria um dos motivos que conduziam grande parte das mulheres à turma de Alfabetização/Nivelamento. Para as estudantes do Ensino Fundamental, o término da escolarização básica parecia ainda distante e, por isso, desanimavam com mais facilidade e desistiam das aulas. Para as discentes do Ensino Médio, a possibilidade de concluir essa modalidade e ingressar no vestibular, parecia impulsioná-las a estudar.

Entretanto, o acompanhamento das aulas por meio das observaçóes nos davam indícios de que havia algo para além da relação pragmática "frequênciaremiçâo de pena”. O clima das aulas era agradável para a maioria das estudantes. A sala de aula era também o lugar isento da vigilância e do controle e, portanto, constituía-se em local privilegiado de liberdade de expressão e de pensamento.

$\mathrm{O}$ espaço da sala de aula era o ponto de encontro entre as mulheres que ficavam em diferentes alojamentos e proporcionava o diálogo entre si. Assim como o momento do recreio na escola frequentada fora do presídio, a sala de aula no espaço prisional garantia a sociabilidade ${ }^{6}$ constituída, não apenas nas brincadeiras e na descontração, como também nas amizades que se firmavam na escola a partir do auxílio mútuo na execução de tarefas escolares:

Olha, a gente aqui se dá bem. E a gente se ajuda nas tarefas lá dentro [nos alojamentos do presídio]. (Estudante, 39 anos, Alfabetização/ Nivelamento).

E!' Quem sabe mais, que mora com a gente, ajuda a escrever, a fazer o tema que a professora manda. (Estudante, 40 anos, Alfabetização/ Nivelamento).

Evidentemente, o retorno à escolarização não era repleto de experiências aprazíveis. Para além da dificuldade de retomar os estudos após muito tempo de interrupçôes, de apropriar-se dos códigos formais da escrita, da leitura e dos 
cálculos matemáticos, algumas estudantes se deparavam com os efeitos adversos das medicaçóes tomadas no presídio, das noites mal dormidas e dos resquícios deixados pelo uso de algumas drogas (em especial o crack) na capacidade de concentração e agilidade de raciocínio. Em certos dias, era impossível dar continuidade às aulas, pois as estudantes não conseguiam acompanhar as atividades ou por causa de uma das razóes acima citadas ou, ainda, por estarem deprimidas e doentes. A condição de mulher "presidiária" também adentrava a sala de aula e, por esse motivo, era preciso habilidade do professor para saber contornar ou mediar as situaçốes advindas dessa condição.

Diante dos prazeres e das dificuldades encontradas no retorno à escola, foi possível perceber um outro sentido atribuído pelas mulheres ao processo de escolarização no presídio: na frequência às aulas, (re)descobria-se o gosto por estudar:

$E u$ [voltei a estudar no presídio] pra preencher o tempo e aprender mais. Aí depois eu vi que valia a pena aprender mais. Eu vi o esforço dos professores. Aqui a gente tem uma visão mais ampla do mundo pelos olhos dos professores. A gente fica lá dentro [da cela], aquela coisa. Aquelas conversas. Ai vem aqui é como se abrisse uma janela pra mim. Eu olho lá fora, longe. Eu fico triste quando não tem aula. Aquele dia que não tiraram a gente e nós parado ali e dava pra ver na cara dos professores e dos estagiários a decepção... Eu chego lá [na cela] eu falo: fui pra aula! Vamos? Eu fico feliz quando vou pra aula. Claro, por causa da remição também. Fora a alegria de estudar. Ai a gente quer conversar com elas [colegas de cela] e elas não acompanham porque naquele mundinho fechado. Eu já enxergo além. Fico lá esperando... dar continuidade lá fora nos estudos. Peguei gosto nos estudos. (Estudante, 42 anos, Ensino Fundamental).

Mas assim ó, acho que o estudo... Eu vou poder sair e ler um ônibus, vou poder ensinar pros meus filhos e eles me ensinarem as coisas da escola. Eu vou assinar os documentos! Eu vou poder pegar uma receita assim ó e fazer um prato bonito... Cozinhar uma comida boa... porque en cozinho muito bem, sabe? Aprender a falar melhor. Se não tem estudo, não sabe conversar. [...] Eu quero estudar. 
Aprender mais! Tirar minha carta de motorista, eu quero ter essa liberdade de sair daqui ali. E ter meu negocinho, né? Um bar, um mercado... sei lá... (Estudante, 39 anos, Alfabetização/ Nivelamento).

Quando foi estabelecida a relação entre as experiências escolares anteriores à prisão e a experiência escolar atual, foi possível notar entre aquelas que tiveram trajetórias escolares mais longas, como a concepção de educação proposta para os espaços prisionais se diferenciava em termos de reconhecer aos estudantes a condição de sujeitos de direitos:

Pra mim, as matérias são as mesmas. Mas você tem mais acesso a eles [aos professores]. (Estudante, 56 anos, Ensino Médio).

Lá [na escola fora do presídio] eu não falava muito. Acho que aqui tem menos pessoas. Aqui você tem voz e vez. [...] A professora de Geografia, a estagiária, trouxe as coisas pra dar uma aula. E queria que a gente falasse, não tem? Mas acho que as pessoas não estão acostumadas a falar. Eu vi que ela ficou assim... também que o professor tem aquele jeito de falar, falar... acho que as pessoas não são acostumadas. (Estudante, 22 anos, Ensino Médio).

A paciência que os professores têm [na escola do presídio]. Eles conseguem passar pros alunos o que eles querem ensinar. Já peguei professor que era uns carrasco, não conseguia aprender nada! Eu tinha medo. (Estudante, 42 anos, Ensino Fundamental).

A jovem que havia concluído o Ensino Médio e que frequentava as aulas como ouvinte teve uma passagem anterior pelo presídio feminino e estudou durante o tempo em que cumpria pena. Ela analisa o processo de precarização sofrido pela escola do presídio ao longo dos anos e consegue perceber a tensa relação entre a proposta educativa da instituição escolar e a concepção punitiva e restritiva pela qual se pauta o sistema prisional:

Devia ser um pouquinho mais abrangente. Tem mais épelo professor. Se tivesse oportunidade de trazer mais coisas, mas náo pode nada! Antes tinha uma biblioteca aqui na sala. 
Lembra, professora? Quem cuidava eram uns alunos da faculdade. Tinha um monte de livro! A gente podia pegare levar os livro pra ler no alojamento. Depois trazia de volta. Mas, por causa da segurança não se pode ter mais nada! Ai fica por conta do professor se virar! (Estudante, 26 anos, Ensino Médio).

Era com o passar o tempo que essas percepçóes sobre a escola como um espaço de liberdade e de reconhecimento da identidade das estudantes se tornava compreensível e que novos sentidos passavam a ser atribuídos à escolarização no presídio feminino.

\section{Considerações Finais}

A pesquisa empírica nos propiciou traçar comparativos entre as experiências escolares que antecederam o período de reclusão no presídio e aquelas tecidas na escola do complexo penitenciário. A análise das trajetórias escolares nos permite evidenciar o papel da mulher no trato cultural sobre a escolarização: existiram nos relatos, mençóes quanto à impossibilidade de continuar os estudos porque esse não seria necessário às mulheres; situações de abandono do processo de escolarização por causa de casamentos; e, ainda, histórias que narram a saída da escola em razão da incompatibilidade entre a situaçáo de gestante e a de estudante.

As situações de gênero que atravessaram as trajetórias de vida dessas estudantes apontam para o lugar social, histórico e culturalmente destinado às mulheres: a esfera doméstica, o cuidado com os filhos e a subserviência aos maridos. A escolarização ocuparia um espaço secundário dentre as atividades consideradas mais importantes à vida das mulheres. Quando o retorno aos estudos se fez possível após uma interrupção, esbarrou-se nas dificuldades de garantir acesso e permanência às estudantes trabalhadoras e mães.

Ao considerar as experiências escolares tecidas na escola da penitenciária foi possível notar um movimento de entrada e permanência na escola: se, a princípio, a aproximaçáo com o espaço escolar na prisão se justificava pela ocupação do tempo ocioso ou pela possibilidade de remir dias da pena - como apontado por Julião (2007); essa relação com a instituição escolar passava a ganhar novos contornos quando se (re)descobria o gosto por estudar. 
Esse fato pode estar relacionado à dinâmica de aula e de relaçôes tecidas entre professores e estudantes na escola do presídio. $\mathrm{O}$ número reduzido de estudantes em sala de aula, o acompanhamento próximo das atividades desenvolvidas e a possibilidade de diálogo aberto entre professores e estudantes ressignificavam a experiência escolar.

Foi possível compreender que o lugar ocupado pela instituição escolar no sistema prisional e a concepção de EJA para os espaços prisionais presente nas práticas dos professores da escola contribuíram para dar novo sentido ao processo de escolarização. A escola e o corpo docente trabalhavam na contramáo do processo de "des-identificação" das mulheres privadas de liberdade, promovido pela política prisional de consolidaçáo de uma identidade de presidiária, com um número de registro, submissa às ordens e normas impostas pelo presídio. $\mathrm{Na}$ escola recuperavam-se nomes e a historicidade da trajetória de vida das estudantes, que podiam ser ouvidas pelos professores - como também observado por Onofre (2007) e Santos (2007) em suas pesquisas.

Sendo assim, pode-se arriscar em dizer que esse novo sentido atribuído à escolarização e à experiência escolar somente se fazia possível porque a escola estava inserida no sistema prisional e ali encontrava seu papel/função com mais clareza com que as instituiçōes escolares que se situavam fora do sistema prisional. Sem a intenção de produzir uma visão romanceada a respeito da educação de jovens e adultos nos espaços prisionais, era em meio àquelas condiçóes que a premissa de desenvolver uma prática educativa que problematizasse as condiçóes de vida e os motivos que levaram a cometer crimes, conferia à sala de aula um lugar propício para se projetar a vida para além da prisão. Parecia ser naquele espaço o encontro com os aprendizados importantes para a vida que ampliavam os horizontes de mulheres que, durante o cumprimento da pena no presídio, não conseguiam vislumbrar outra condição a não ser de presidiária.

\section{Notas}

${ }^{1}$ Disponível em: <http://www.mj.gov.br>. Acesso em: 2 mar. 2009.

${ }^{2}$ Disponível em: <http://portal.mj.gov.br/data/Pages/74E9CEITEMI DC37B2AE94C6840068B1624D28407509CPTBRIE.htm>. Acesso em: 20 jul. 2011.

${ }^{3}$ Carreira (2009, p. 11) faz uma ressalva a esse documento: "Segundo 
Graciano (2005), o documento "Regras Mínimas" apresenta três grandes entraves ao reconhecimento do direito humano à educação de pessoas presas. $\mathrm{O}$ primeiro deles contribui para a confusão entre educação formal, ensino religioso e educaçáo não-formal. $O$ segundo: restringe a obrigatoriedade do Estado em oferecer educação apenas em relação à alfabetização. $\mathrm{O}$ terceiro: torna facultativa a integração da educação penitenciária ao sistema regular de ensino".

${ }^{4}$ É importante registrar que não houve disponibilização dos documentos da instituição escolar pesquisada. As informaçôes obtidas sobre o histórico da escola e a missão institucional se encontram presentes em um banner exposto no corredor do espaço escolar e no sítio eletrônico da Penitenciária, disponível em: <http://www.penitenciariafpolis.com.br/>. Acesso em: 4 jun. 2012.

${ }^{5}$ Os números se referem aos registros de matrícula computados no segundo semestre de 2012.

${ }^{6}$ Entende-se neste trabalho que "a sociabilidade não busca resultados exteriores concretos e seu alvo imediato é o sucesso da interação, o fascinante jogo de relaçóes que se cria entre os participantes. Por outro lado, o caráter lúdico da sociabilidade advém, também, do fato de ser uma metáfora da vida, um "jogo social": a sociabilidade joga com as formas da sociedade. É nesse sentido que a sociabilidade proporciona um sentimento de alívio e liberação em relação às pressóes cotidianas da vida: as forças carregadas de "conteúdo" da realidade estarão presentes, porém, de uma forma diluída e sublimadas no jogo simbólico que se estabelecerá entre os participantes, configurando uma miniatura do ideal societário." (DURAND, 2001, p. 5-6).

\section{REFERÊNCIAS}

ALVISI, Cátia; ZAN, Dirce Djanira Pacheco. Cárcere, currículo e o cotidiano prisional: desafios para o direito humano à Educação. Políticas Educativas, Porto Alegre, v. 5, n. 1, p. 32-44, 2011. Disponível em: <http:// seer.ufrgs.br/Poled/article/viewFile/35731/23233>. Acesso em: 15 fev. 2014.

BOURDIEU, Pierre. A dominação masculina. Rio de Janeiro: Betrand Brasil, 1999. 
BRASIL. Ministério da Educação. Conselho Nacional de Educação Básica. Câmara de Educação Básica. Resolução, no 2, de 19 de maio de 2010.

Dispóe sobre as Diretrizes Nacionais para a oferta de educação para jovens e adultos em situação de privação de liberdade nos estabelecimentos penais. Diário Oficial da União, Brasília, DF, 20 maio 2010.

BRASIL. Lei no 12.433 , de 29 de junho de 2011. Altera a Lei no 7.210, de 11 de julho de 1984 (Lei de Execução Penal), para dispor sobre a remição de parte do tempo de execução da pena por estudo ou por trabalho. Diário Oficial da União, Brasília, DF, 30 jun. 2011.

CARREIRA, Denise. Relatoria Nacional para o Direito Humano à Educação: educação nas prisóes brasileiras. São Paulo: Plataforma DhESCA Brasil, 2009. Disponível em: <http://www.dhescbrasil.org.br/attachments/289_ Educa \%C3\%A7\%C3\%A3o\%20nas\%20pris\%C3\%B5es\%20do\%20Brasil. pdf>. Acesso em: 10 jul. 2012.

CHARLOT, Bernard. Da relação com o saber: elementos para uma teoria. Tradução de Bruno Magne. Porto Alegre: Artes Médicas Sul, 2000.

DURAND, Olga Celestina da Silva. Formas associativas juvenis: o caso dos jovens da ilha de santa Catarina. In: REUNIÃO ANUAL ASSOCIAÇÃO NACIONAL DE PÓS-GRADUAÇÃO E PESQUISA EM EDUCAÇÃO, 24., 2001, Caxambu. Anais... Caxambu, MG: Anped, 2011. Disponível em: <http://www.portalanpedsul.com.br/admin/uploads/2000/Gestao_e_ Politicas/Comunicacao/11_29_38_4185.pdf>. Acesso em: 20 jul. 2012.

FERREIRA, Andréa Tereza Brito. Ler e escrever também é uma questão de gênero. In: LEAL, Telma Ferraz. Desafios da educação de jovens e adultos: construindo práticas de alfabetização. Belo Horizonte: Autêntica, 2005.

IRELAND, Timothy D. Anotaçôes sobre a educação em prisões: direito, contradiçóes e desafios. In: CRAIDY, Carmen M. (Org.). Educação em prisóes: direito e desafio. Porto Alegre: Editora da UFRGS, 2010.

IRELAND, Timothy D. Educação em prisões no Brasil: direito, contradiçôes e desafios. Em Aberto, Brasília, v. 24, n. 86, p. 19-39, nov. 2011. Disponível em: <http://emaberto.inep.gov.br/index.php/emaberto/ article/view/2576/1765>. Acesso em: 10 out. 2013. 
JULIÃO, Elionaldo Fernandes. As políticas de educação para o sistema penitenciário. In: ONOFORE, Elenice M. Camarosano (Org.). Educação escolar entre as grades. São Carlos, SP: Editora da UFSCar, 2007.

MILLER, Stela. Relaçóes significado-sentido nos processos de ensino e de aprendizagem. In: ENCONTRO BRASILEIRO DE EDUCAÇÃO E MARXISMO, 5., 2010, Florianópolis. Anais... Florianópolis, SC: UFSC, 2010 Disponível em: <http://www.5ebem.ufsc.br/trabalhos/eixo_05/e05g_ t006.pdf>. Acesso em: 16 out. 2013.

NAKAYAMA, Andréa Retting. O trabalho de professores/as em "um espaço de privação de liberdade": necessidades de formação continuada. 226f. 2011. Dissertação (Mestrado em educação) - Universidade Federal de Santa Catarina, Florianópolis, SC, 2011.

ONOFRE, Elenice M. Camarosano. Escola da prisão: espaço de construção da identidade do homem prisionado? In: ONOFRE, Elenice M. Camarosano (Org.). Educação escolar entre as grades. São Carlos, SP: Editora da UFSCar, 2007.

SANTOS, Silvio dos. A educação escolar na prisão sob a ótica de detentos. In: ONOFORE, , Elenice M. Camarosano (Org.). Educação escolar entre as grades. São Carlos: EdUFSCar, 2007.

SOUZA, Maria Celeste Reis Fernandes de Souza et al. Gênero e currículo: olhares sobre a educação em espaços de privação de liberdade. Revista Eletrônica de Educação, São Carlos, SP, v. 7, n. 1, maio 2013. Disponível em: $<$ http://www.reveduc.ufscar.br/index.php/reveduc/article/view/628>. Acesso em: 10 out. 2013.

TEIXEIRA, Carlos José Pinheiro. O projeto educando para a Liberdade e a política de educação nas prisões. In: CRAIDY, Carmem Maria. Educação em prisóes: direito e desafio. Porto Alegre: Editora da UFRGS, 2010.

WACQUANT, Löic. As prisões da miséria. Rio de Janeiro: Jorge Zahar, 2001. 


\section{La Educación de Jóvenes y Adultos dentro del Espacio Carcelario: sentidos de la escolarización de mujeres impedidas de libertad}

\section{Resumen}

El derecho a la Educación Carcelaria se basa en el principio constitucional del derecho para todos a la educación. Las características del contexto penitenciario requieren del desarrollo de políticas educacionales capaces de atenderlos. Este artículo pretende analizar de qué manera la Educación de Jóvenes y Adultos se introduce en el espacio de la prisión y cuáles serían los sentidos de escolarización de las mujeres estudiantes impedidas de libertad. La investigación que ha inspirado este artículo pretende responder el siguiente problema: ¿cuál es el sentido de las experiencias escolares vividas por las mujeres detenidas en los diferentes momentos de su vida? La investigación tuvo un enfoque cuantitativo y cualitativo, contando con instrumentos de colecta de datos: análisis documental, observación activa, entrevistas y aplicación de cuestionarios. $\mathrm{Al}$ analizar las experiencias escolares realizadas en la escuela de la prisión fue posible percibir un movimiento de entrada y permanencia en ella: al principio la aproximación se justificaba por la ocupación del tiempo desocupado o por la disminución de días de pena, sin embargo, esa relación con los estudios era redimensionada cuando se (re)descubría

\section{The education of youngsters and adults in prison area: meanings of schooling for women in custody}

\section{Abstract}

The right to education in prison is based on the constitutional principle of the right to education for all. The specificities of the prison environment require the development of educational policies able to atend them. This article aims to analyze how the education of young and adults is inserted in the prison space and what are the meanings of schooling for women students in custody. The research that inspired this study was intended to answer the following problem: How are the school experiences meaningful to the women $\otimes_{s}$ life experience who are in justice custody? The research had an qualitative-quantitative approach and data collection instruments were used: document analysis, participant observation, interviews and questionnaires. By analyzing the school experiences approached into the prison school, it was possible to observe an action of entrance and permanence in school: at first, the approach was justified by the occupation of idle time or to decrease days of penalty, however, this relationship with study was resized when a taste for studying was (re) discovered. The place occupied by the academic institution and the idea of adult education for prison spaces contributed 
el placer por el estudio. El lugar ocupado por la institución escolar y la concepción de la EJA en relación a los espacios carcelarios contribuyeron para dar un nuevo sentido a la escolarización: se recuperaban los nombres, la historicidad de la trayectoria de vida de las estudiantes y se problematizaba sobre las condiciones de vida y los motivos que las condujeron a cometer crímenes, así como visualizar posibles proyecciones para el futuro.

Palabras claves: Educación de Jóvenes y Adultos. Mujeres Prohibidas de libertad. Sentidos de Escolarización. to give new meaning to schooling: names were recovered, the historicity students' life trajectory and questions about the living conditions and the reasons to commit crimes, have become possible projections for a future.

Keywords: Education of Youngsters and Adults. Women in custody. Meanings of schooling.

\section{Pollyana dos Santos}

E-mail: pollyanadossantos@yahoo.com.br

\section{Olga Celestina da Silva Durand}

E-mail: olgadumu@hotmail.com

Recebido em: 22/11/2013

Versão final recebida em: $25 / 1 / 2014$

Aprovado em: 30/1/2014 